\title{
PREDICTION OF ANTI-PARKINSON POTENTIAL OF PHYTOCONSTITUENTS USING PREDICTION OF ACTIVITY SPECTRA OF SUBSTANCES SOFTWARE
}

\author{
RAJAN KUMAR, RAKESH KUMAR, ABHINAV ANAND, NEHA SHARMA, NAVNEET KHURANA* \\ Department of Pharmaceutical Sciences, Lovely Professional University, Phagwara, Punjab, India. \\ Email: navi.pharmacist@gmail.com
}

Received: 05 March 2018, Revised and Accepted: 12 April 2018

\section{ABSTRACT}

Objective: Neurodegenerative disorders are group of diseased conditions in which there is loss of neuron cells occur. The main objective of this study to find/search out the phytochemical with the help of prediction of activity spectra of substances (PASS), those show maximum activity over the selected targets of the Parkinson's disease (PD).

Methods: PASS is a valuable software which is used in this study, to predict the anti-Parkinson activity of different compounds. Canonical simplified molecular-input line-entry system is used for the prediction of anti-Parkinson activity which is obtained from PubChem website. The predicted activity also compared with marketed compound like levodopa.

Results: From the study, it was found that resveratrol was the only compound which has the activity on all the selected targets. On the other hand, stemazole and celastrol were found to have the least active compounds as both have the activity only on a single target.

Conclusion: In this research work, we tried to compile the information regarding the PASS predicted anti-Parkinson activity of some important phytoconstituents. We found that resveratrol can be a target for further investigation in the development of drug therapy for PD.

Keywords: Parkinson's disease, Prediction of activity spectra of substances, Levodopa, Postural instability

(C) 2018 The Authors. Published by Innovare Academic Sciences Pvt Ltd. This is an open access article under the CC BY license (http://creativecommons. org/licenses/by/4. 0/) DOI: http://dx.doi.org/10.22159/ajpcr.2018.v11s2.28578

\section{INTRODUCTION}

Parkinson disease (PD) is the second most common, age-related chronic neurodegenerative disorder. Nowadays, PD is the most prevalent disease. Approximate 7-10 million people of the world surviving with the PD, of these 1 million lives in the U.S. men are at a greater risk of PD compared to woman. As the age increases, the incidence of PD also increases. Mostly the people with the age of 60 years or above are the targets of the PD. PD becomes the $14^{\text {th }}$ leading cause of death in the U.S [1,2]. The key symptoms of PD are tremors, rigidity, bradykinesia, postural instability, cognitive dysfunction, and sleep disturbance. These symptoms appeared due to progressive loss of dopaminergic neurons in substantia nigra pars compacta of brain, which further lead to loss of dopamine (DA) $[2,3]$. Another pathological hallmark of PD is the presence of eosinophilic intracytoplasmic proteinaceous inclusion bodies that are mainly composed of fibrillar $\alpha$-synuclein termed Lewy bodies and dystrophic neurites (Lewy neurites) presents in surviving neurons [4].

The etiology of PD is still unknown, but there are several factors such as environmental, genetics, age, and medication which can be responsible for the development of PD. The available drug therapy which includes levodopa and carbidopa provide only symptomatic relief but able to cure the underline cause of the PD. These drugs also produce certain side effects such as nausea, vomiting, hallucination, convulsions, and dry mouth (Fig. 1) [1,5].

Herbal medicines have a long history of safe and efficacious administration as therapeutic agent or dietary supplement in different parts of the world. Due to the presence of various type of phytochemical in them, these herb possesses protective and therapeutic effect in various indications. Nowadays, plant chemicals are of great interest for the development of medicine for various diseases [6]. Development of new safe and effective medicine is not an easy task. Various phytochemicals have been reported to be effective in in vitro and in vivo models of $\mathrm{PD}$, but no one can enter into the mainstream of drug development due to lack of information.

Prediction of activity spectra for substances (PASS) is a computer-based software, which provides the information regarding the biological activities on different targets of the chemical compound on the bases of their chemical structure. The software predicts the activity of the compound in two probabilities; one is probable activity $(\mathrm{Pa})$ and another one is probable inactivity (Pi). The value of $\mathrm{Pa}$ and $\mathrm{Pi}$ varies from 0.000 to 1.000 . If $\mathrm{Pa}>\mathrm{Pi}$ for any activity, only then that activity can be designated to the compound. If Pa value is more than 0.7 for any activity, then the probability of that action is high in pharmacological experiment. If $\mathrm{Pa}$ value is more than 0.5 but $<0.7$ for any activity, then the probability of that action is less in pharmacological experiment. If $\mathrm{Pa}$ value is $<0.5$, then the probability of observing that activity in pharmacological experiment is less [7-10].

\section{METHODS}

For the evaluation of the activity using PASS, first, we select certain phytoconstituents which have already reported to have pharmacological effect in the in vivo and in vitro models of $\mathrm{PD}$, and one marketed standard drug compound for PD that is levodopa. For the prediction of activity in the different targets of $\mathrm{PD}$, canonical simplified molecular-input line-entry system (SMILES) is used which is obtained from PubChem website shown in Table 1. These SMILES work as a molecular formula of the compound and are directly copied into the PASS software to predict the activity.

\section{RESULTS}

The selected phytochemical and marketed compound was predicted using PASS for nine activities in the PD shown in Table 2. These activities are as follows: 


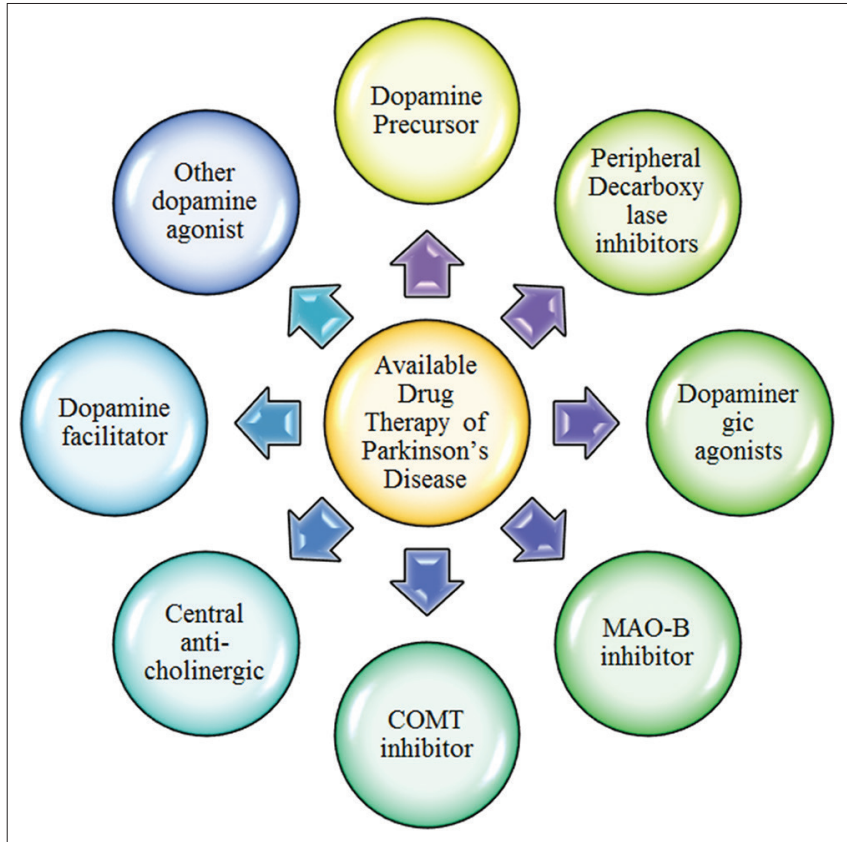

Fig. 1: Available drug therapy of Parkinson disease
- DA precursor

- $\quad$ Caspase 3 inhibitor

- Anticholinergic

- Free radical scavenger

- Nootropic activity

- Monoamine oxidase (MAO) inhibitor

- DA release stimulant

- N-methyl D-aspartate (NMDA) receptor antagonists

- Antiparkinsonian.

The predicted Pa predicted by PASS is represented in Table 2 and also compared with the marketed drug that is levodopa.

\section{DISCUSSION}

$\mathrm{PD}$ is a progressive neurodegenerative disorder, for which till now an effective treatment is not available. Research is going on overall the world in this stream. Several compounds have passes the preclinical trails but able to come into the clinical trial phase, due to lack of informative data. PASS is online software, which can be used by anyone after completing free registration. This software predicts the biological activity of the chemical compound on the bases of chemical structure and interaction with the different targets. This software provides an information regarding that a particular compound can be beneficial in a particular disease. On the basis of which further pharmacological

Table 1: Phytochemicals with canonical SMILES and chemical structure

\begin{tabular}{ll}
\hline Name of compound & Canonical SMILES \\
\hline Levodopa & $\mathrm{C} 1=\mathrm{CC}(=\mathrm{C}(\mathrm{C}=\mathrm{C} 1 \mathrm{CC}(\mathrm{C}(=\mathrm{O}) \mathrm{O}) \mathrm{N}) \mathrm{O}) \mathrm{O}$
\end{tabular}

Nicotine

Caffeine

Resveratrol

$\mathrm{C} 1=\mathrm{CC}(=\mathrm{CC}=\mathrm{C} 1 \mathrm{C}=\mathrm{CC} 2=\mathrm{CC}(=\mathrm{CC}(=\mathrm{C} 2) 0) 0) 0$

Riluzole

$\mathrm{C} 1=\mathrm{CC} 2=\mathrm{C}(\mathrm{C}=\mathrm{C} 10 \mathrm{OC}(\mathrm{F})(\mathrm{F}) \mathrm{F}) \mathrm{SC}(=\mathrm{N} 2) \mathrm{N}$
$\mathrm{CN} 1 \mathrm{CCCC} 1 \mathrm{C} 2=\mathrm{CN}=\mathrm{CC}=\mathrm{C} 2$

$\mathrm{CN} 1 \mathrm{C}=\mathrm{NC} 2=\mathrm{C} 1 \mathrm{C}(=0) \mathrm{N}(\mathrm{C}(=0) \mathrm{N} 2 \mathrm{C}) \mathrm{C}$<smiles>N[C@@H](Cc1ccc(O)c(O)c1)C(=O)O</smiles><smiles>Cn1c(=O)c2c(ncn2C)n(C)c1=O</smiles>

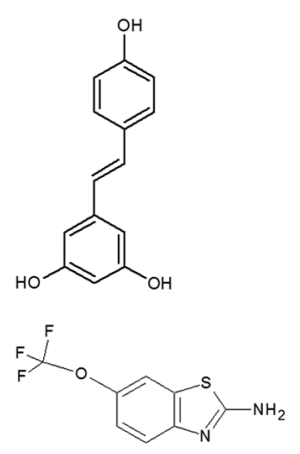


Table 1: (Continued)

Name of compound

Hesperidin

Baicalein

Acetylcholine

n-Butylidenephthalide

Stemazole

Celastrol

L-theanine

Kaempferol

Carnosic acid
Canonical SMILES

CC1C (C (C (C (01) OCC2C (C (C (C (O2) OC3=CC $=\mathrm{C} 4 \mathrm{C}(=0)$ $\mathrm{CC}(\mathrm{OC} 4=\mathrm{C} 3) \mathrm{C} 5=\mathrm{CC}(=\mathrm{C}(\mathrm{C}=\mathrm{C} 5)$ OC) 0) 0) 0) 0) 0) 0) 0$) \mathrm{O}$

$\mathrm{C} 1=\mathrm{CC}=\mathrm{C}(\mathrm{C}=\mathrm{C} 1) \mathrm{C} 2=\mathrm{CC}(=0) \mathrm{C} 3=\mathrm{C}(\mathrm{C}(=\mathrm{C}(\mathrm{C}=\mathrm{C} 302) 0) 0) \mathrm{O}$

$\mathrm{CC}(=0)$ 0C1CC2 $=\mathrm{CC} 3=\mathrm{C}(\mathrm{C}=\mathrm{C} 2 \mathrm{C} 4 \mathrm{C} 1(\mathrm{C} 5=\mathrm{C}(\mathrm{CN} 4 \mathrm{C}) \mathrm{C} 6=\mathrm{C}(\mathrm{C}=\mathrm{C} 5)$ OC06) C) $0 \mathrm{CO} 3$

$\mathrm{CCCC}=\mathrm{C} 1 \mathrm{C} 2=\mathrm{CC}=\mathrm{CC}=\mathrm{C} 2 \mathrm{C}(=0) \mathrm{O} 1$

$\mathrm{C} 1=\mathrm{CC}(=\mathrm{CC}=\mathrm{C} 1 \mathrm{C} 2=\mathrm{NNC}(=\mathrm{S}) 02) \mathrm{NC}(=\mathrm{S}) \mathrm{NN}$

$\mathrm{CC} 1=\mathrm{C}(\mathrm{C}(=0) \mathrm{C}=\mathrm{C} 2 \mathrm{C} 1=\mathrm{CC}=\mathrm{C} 3 \mathrm{C} 2(\mathrm{CCC} 4(\mathrm{C} 3(\mathrm{CCC} 5(\mathrm{C} 4 \mathrm{CC}(\mathrm{CC} 5)(\mathrm{C})$ $\mathrm{C}(=0)$ O) C) C) C) C) $\mathrm{O}$

$\operatorname{CCNC}(=0) \operatorname{CCC}(\mathrm{C}(=0) 0) \mathrm{N}$

$\mathrm{C} 1=\mathrm{CC}(=\mathrm{CC}=\mathrm{C} 1 \mathrm{C} 2=\mathrm{C}(\mathrm{C}(=0) \mathrm{C} 3=\mathrm{C}(\mathrm{C}=\mathrm{C}(\mathrm{C}=\mathrm{C} 302) 0) 0) 0) \mathrm{O}$

$\mathrm{CC}(\mathrm{C}) \mathrm{C} 1=\mathrm{C}(\mathrm{C}(=\mathrm{C} 2 \mathrm{C}(=\mathrm{C} 1) \mathrm{CCC} 3 \mathrm{C} 2(\mathrm{CCCC} 3(\mathrm{C}) \mathrm{C}) \mathrm{C}(=0) 0) 0) \mathrm{O}$
Chemical structure
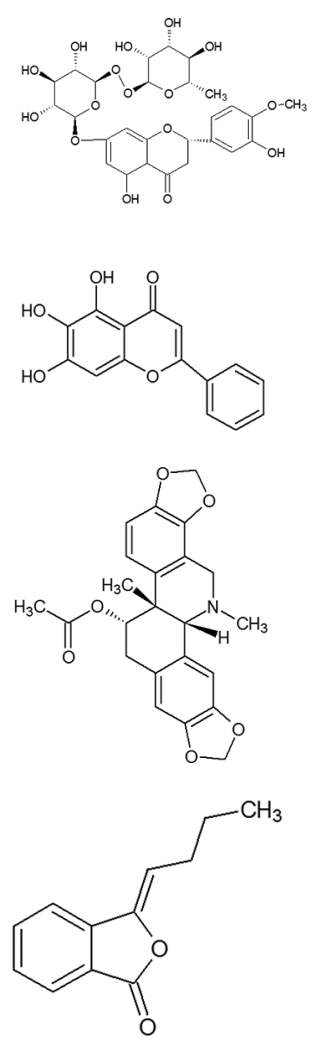<smiles>NNC(=S)Nc1ccc(-c2n[nH]c(=S)o2)cc1</smiles>
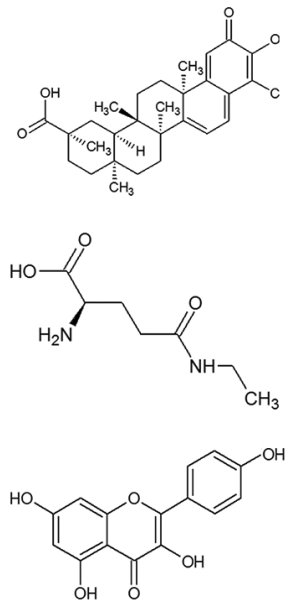<smiles>CC(C)c1cc2c(c(O)c1O)[C@@]1(C)CCCC(C)(C)[C@@H]1CC2</smiles> 
Table 1: (Continued)

\begin{tabular}{|c|c|c|}
\hline Name of compound & Canonical SMILES & Chemical structure \\
\hline Gastrodin & $\mathrm{C} 1=\mathrm{CC}(=\mathrm{CC}=\mathrm{C} 1 \mathrm{CO}) \mathrm{OC} 2 \mathrm{C}(\mathrm{C}(\mathrm{C}(\mathrm{C}(\mathrm{O} 2) \mathrm{CO}) 0) 0) \mathrm{O}$ & \\
\hline Trehalose & $\mathrm{C}(\mathrm{C} 1 \mathrm{C}(\mathrm{C}(\mathrm{C}(\mathrm{C}(\mathrm{O} 1)$ OC2C (C (C (C (O2) CO) 0) 0) 0) 0) 0) 0) 0 & \\
\hline Rosmarinic acid & $\begin{array}{l}\mathrm{C} 1=\mathrm{CC}(=\mathrm{C}(\mathrm{C}=\mathrm{C} 1 \mathrm{CC}(\mathrm{C}(=0) \text { 0) OC }(=0) \mathrm{C}=\mathrm{CC} 2=\mathrm{CC}(=\mathrm{C}(\mathrm{C}=\mathrm{C} 2) 0) \\
\text { 0) 0) } \mathrm{O}\end{array}$ & \\
\hline Shogaol & $\mathrm{CCCCCC}=\mathrm{CC}(=0) \mathrm{CCC} 1=\mathrm{CC}(=\mathrm{C}(\mathrm{C}=\mathrm{C} 1)$ o) OC & \\
\hline Zingerone & $\mathrm{CC}(=0) \mathrm{CCC} 1=\mathrm{CC}(=\mathrm{C}(\mathrm{C}=\mathrm{C} 1) 0) \mathrm{OC}$ & \\
\hline Syringic acid & $\mathrm{COC} 1=\mathrm{CC}(=\mathrm{CC}(=\mathrm{C} 10) \mathrm{OC}) \mathrm{C}(=0) \mathrm{O}$ & \\
\hline Fisetin & $\mathrm{C} 1=\mathrm{CC}(=\mathrm{C}(\mathrm{C}=\mathrm{C} 1 \mathrm{C} 2=\mathrm{C}(\mathrm{C}(=0) \mathrm{C} 3=\mathrm{C}(\mathrm{O} 2) \mathrm{C}=\mathrm{C}(\mathrm{C}=\mathrm{C} 3) 0) 0) 0) \mathrm{O}$ & \\
\hline
\end{tabular}

SMILES: Simplified molecular-input line-entry system

testing can be performed to verify the result or the pre-performed pharmacological testing can get support from the information provided by the software.

In this study, we select certain phytoconstituents which have been reported to have beneficial effects in the in vivo and in vitro models of PD. One marketed standard drug (levodopa) for PD is also selected to compare with the phytoconstituents. All compounds were tested for nine activities as shown in Fig. 2. We found that levodopa has the highest DA precursor activity when compared to the selected phytoconstituents (Fig. 3). Of the phytoconstituents, rosmarinic acid has the higher value for DA precursor activity and fisetin has the lowest one.

The phytoconstituents which show DA precursor activity follow the pattern rosmarinic acid $>$ trehalose $>$ zingerone $>$ L-theanine, resveratrol $>$ gastrodin $>$ syringic acid $>$ shogaol $>$ fisetin .
Levodopa was found to have least caspase 3 inhibitory activity, and only four phytochemicals show caspase 3 inhibitory activity, Fig. 4 . L-theanine has the highest value and resveratrol has the least but more than levodopa. The value varies such as l-theanine $>$ syringic acid $>$ n-butylidenephthalide $>$ resveratrol $>$ levodopa. Similarly, only three phytochemicals show anticholinergic activity nicotine $>$ acetylcholine $>$ resveratrol, and same was absent in case of levodopa.

In case of anticholinergic activity, only three compounds were found to have the anticholinergic activity shown in Fig. 5. Nicotine has the highest activity followed by acetylcholine and resveratrol, respectively.

Hesperidin was found to have the highest free radical scavenging activity shown in Fig. 6. Levodopa also found to have free radical scavenging activity, but most of the phytochemicals were found to have more value for the same activity, Hesperidin $>$ kaempferol $>$ fisetin $>$ 


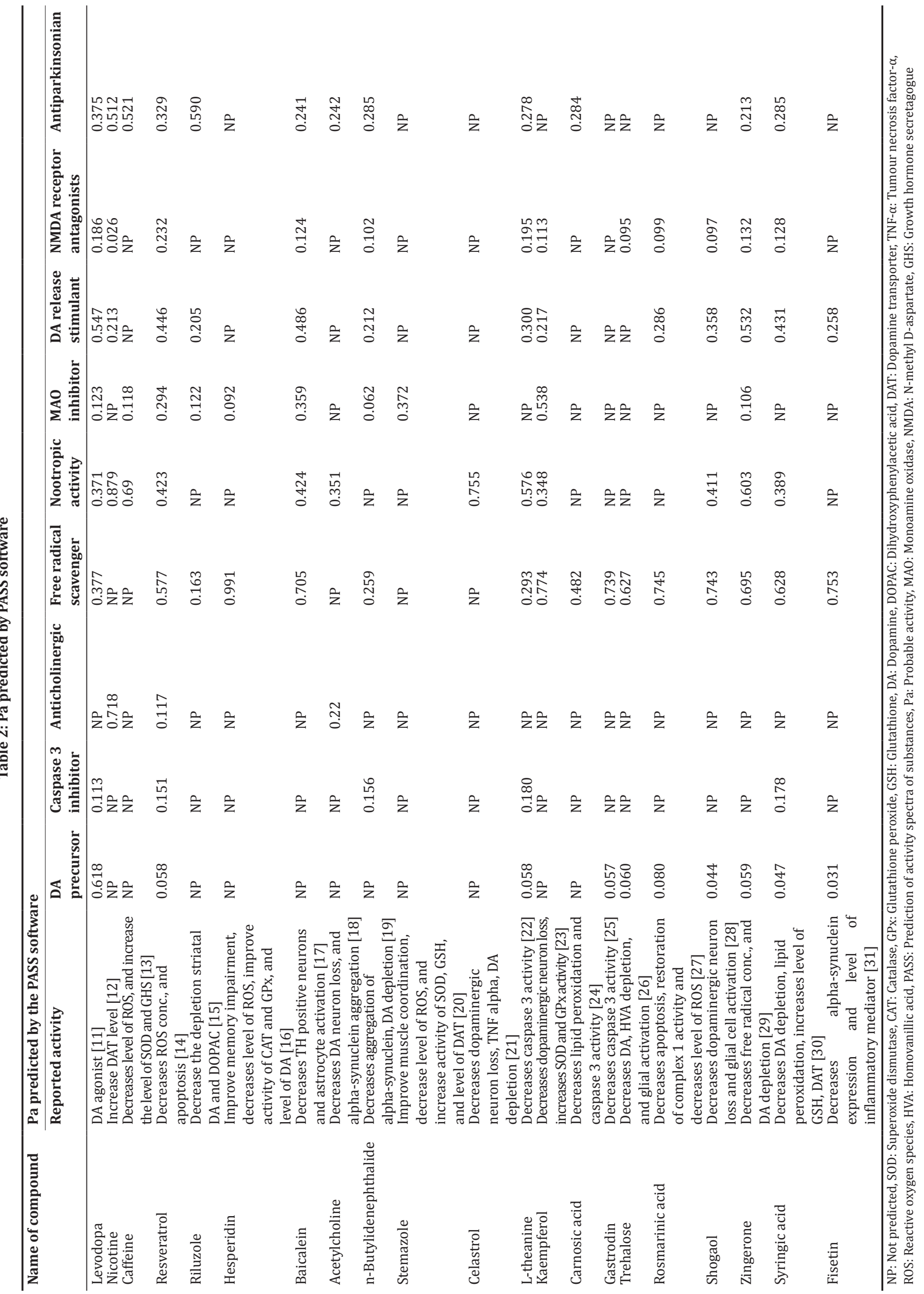




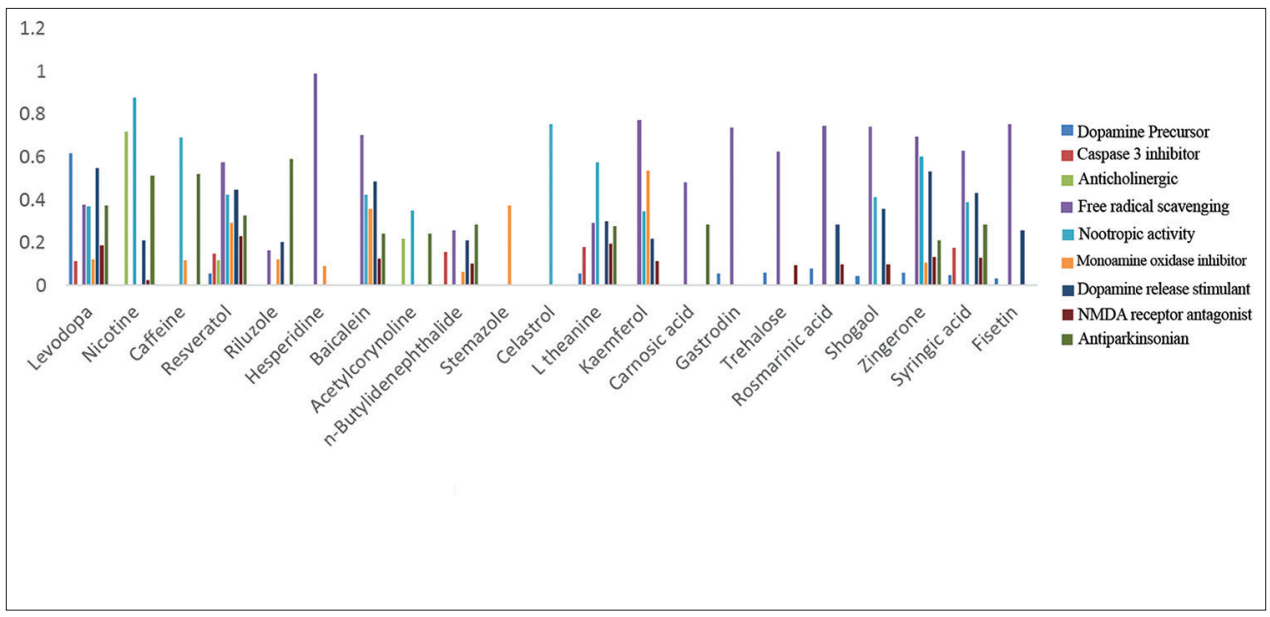

Fig. 2: All activities of all compounds with respect to levodopa

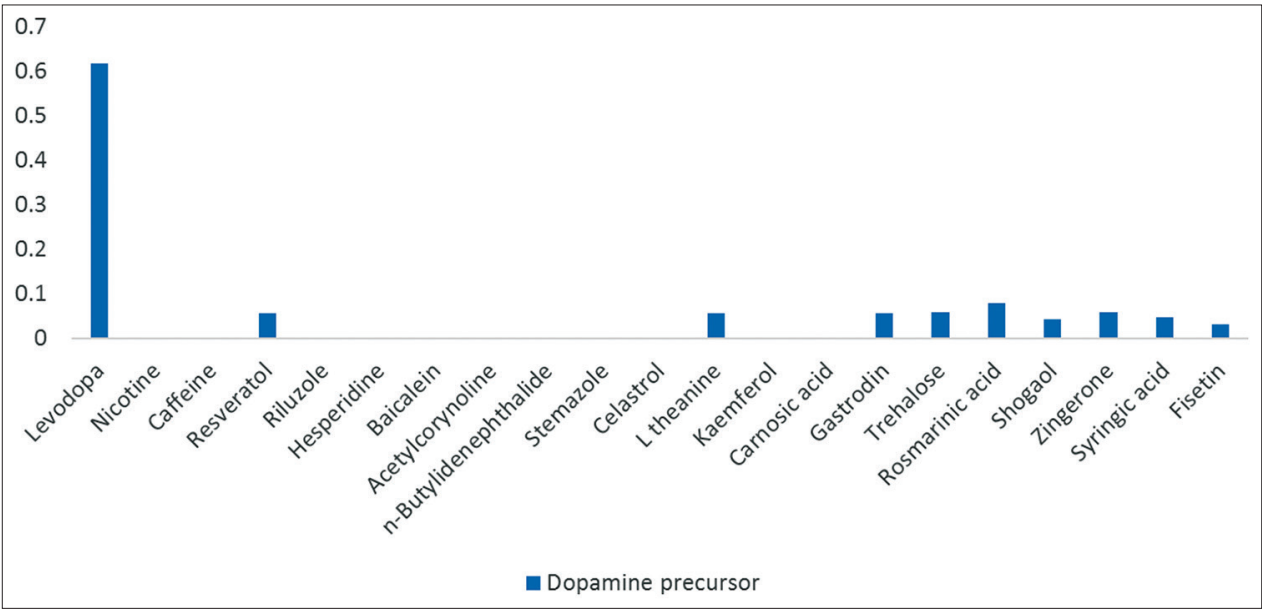

Fig. 3: Dopamine precursor activity of all compounds with respect to levodopa

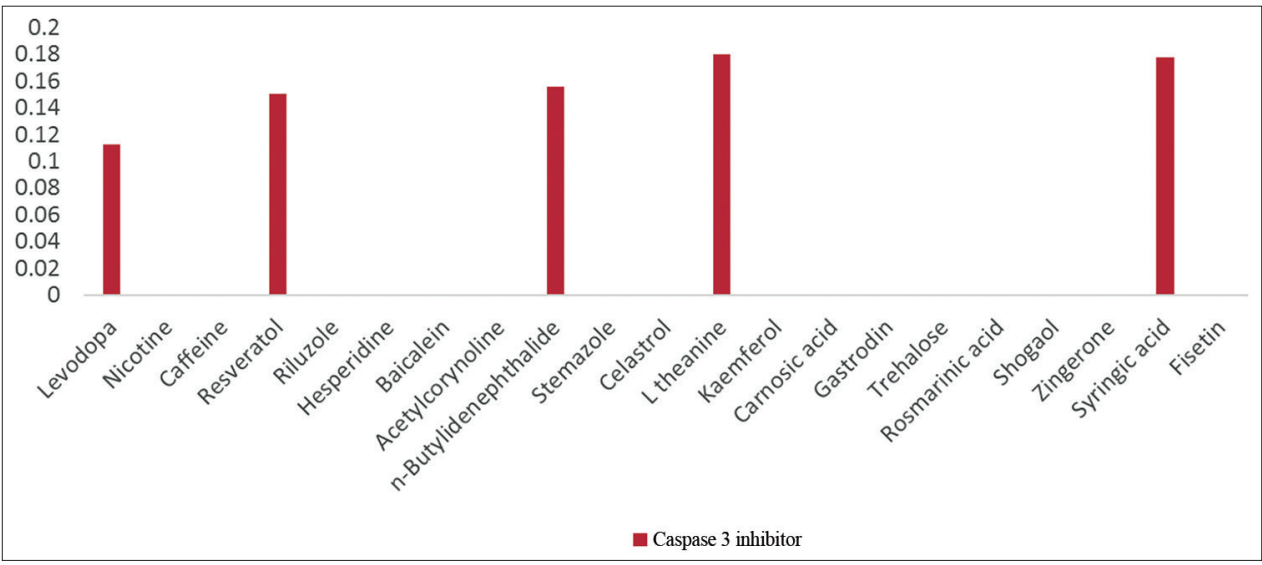

Fig. 4: Caspase 3 inhibitor activity of all compounds with respect to levodopa

rosmarinic acid $>$ shogaol $>$ gastrodin $>$ baicalein $>$ zingerone $>$ syringic acid $>$ trehalose $>$ resveratrol $>$ carnosic acid $>$ levodopa $>$ l-theanine $>$ n-butylidenephthalide > riluzole. Rosmarinic acid and shogaol have value almost near to each other.

Again in case of nootropic activity, most of the phytochemicals have the higher value than the levodopa, and according to value list is like: Nicotine $>$ celastrol $>$ caffeine $>$ zingerone $>$ l-theanine $>$ baicalein $>$ resveratrol $>$ shogaol $>$ syringic acid $>$ levodopa $>$ acetylcholine > kaempferol. Resveratrol, baicalein, kaempferol, and acetylcholine have activity values near to each other shown in Fig. 7.

In MAO inhibiting activity, kaempferol has the highest value than another phytochemicals and also more than levodopa, kaempferol $>$ stemazole $>$ baicalein $>$ resveratrol $>$ levodopa > riluzole > caffeine $>$ zingerone $>$ hesperidin $>$ n-butylidenephthalide as shown in Fig. 8. 


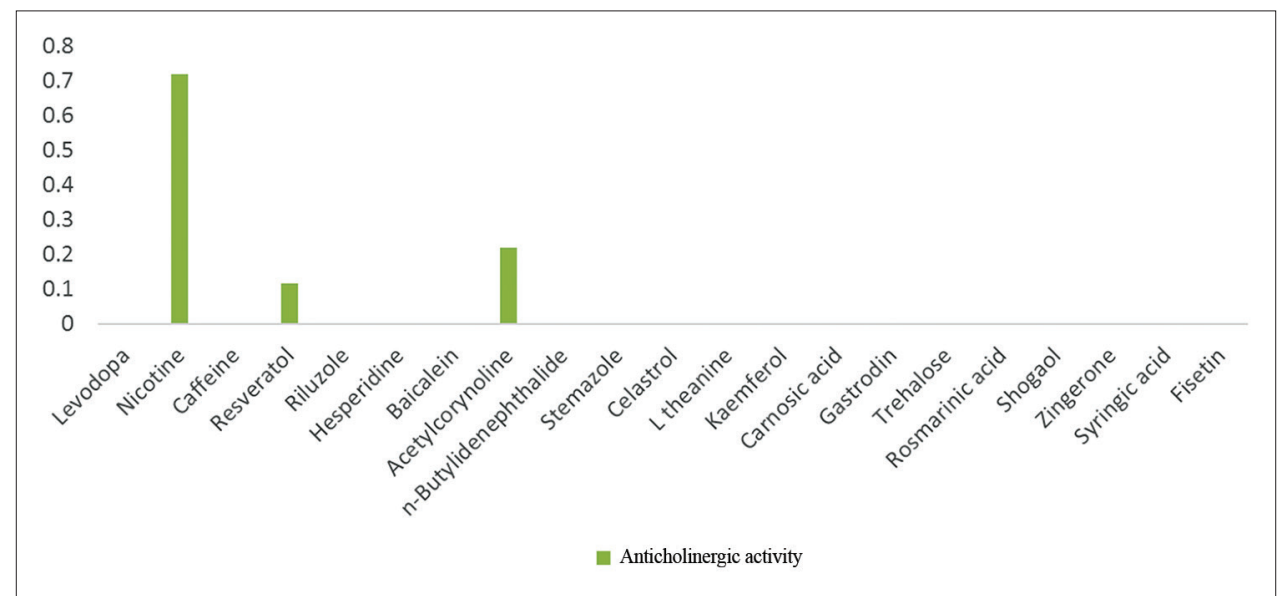

Fig. 5: Anticholinergic activity of all compounds with respect to levodopa

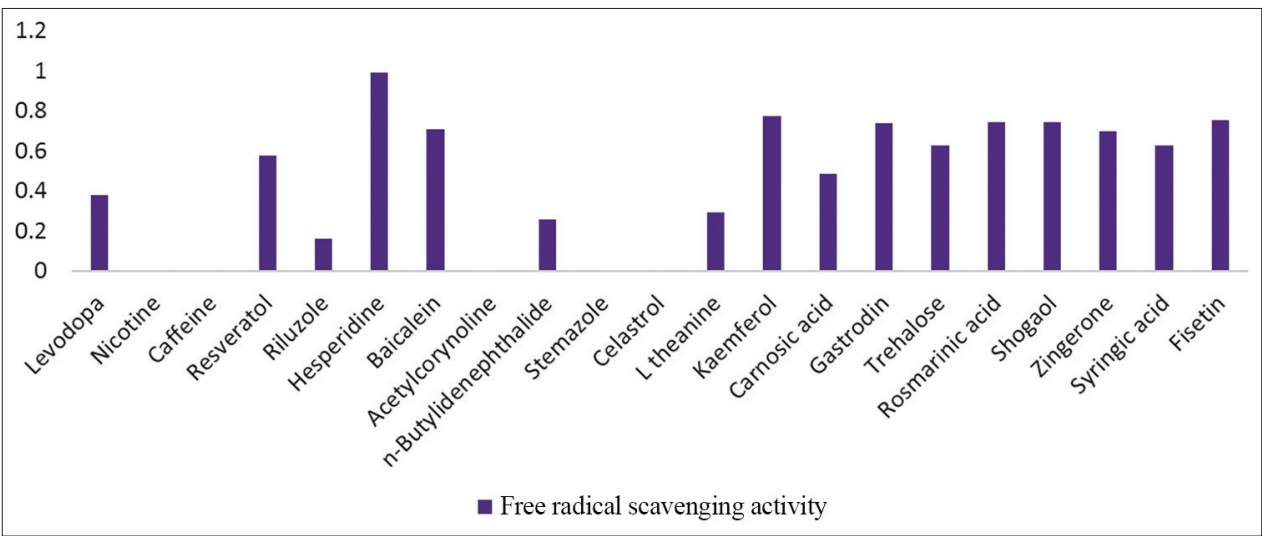

Fig. 6: Free radical scavenging activity of all compounds with respect to levodopa

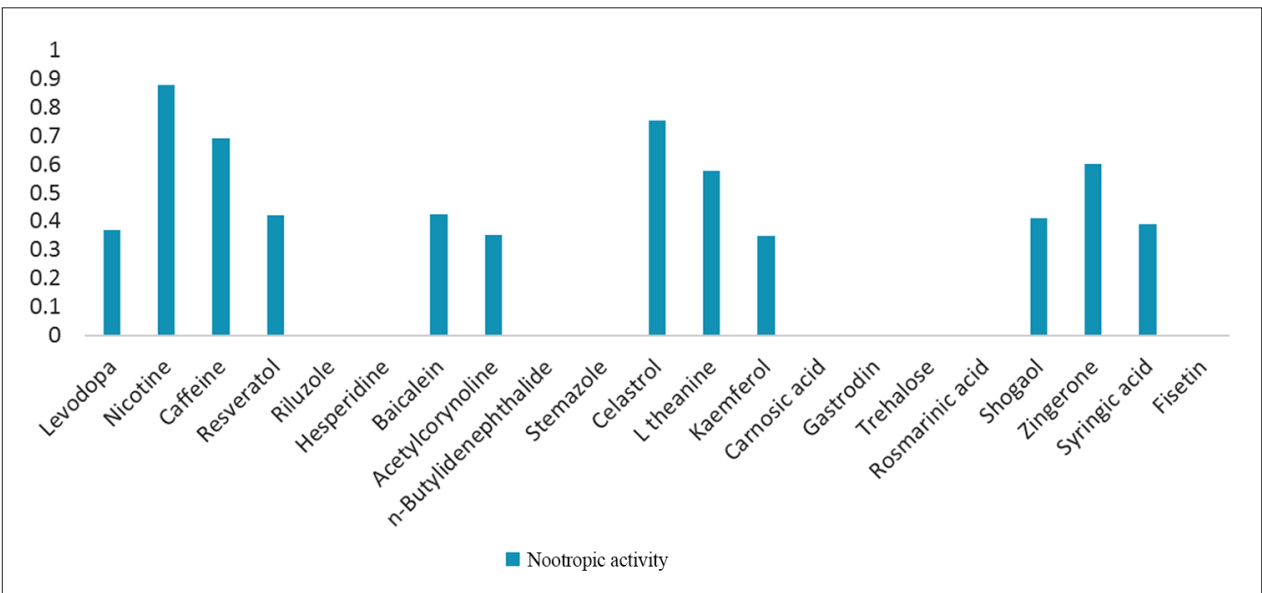

Fig. 7: Nootropic activity of all compounds with respect to levodopa

Levodopa was found to have the highest DA release stimulant activity, when compared to the selected phytochemicals shown in Fig. 9. Zingerone found to have the highest value among the phytochemicals but less than levodopa. Other compounds having DA release activity are as follow: Levodopa $>$ zingerone $>$ baicalein $>$ resveratrol $>$ syringic acid $>$ shogaol $>$ l-theanine $>$ rosmarinic acid $>$ fisetin $>$ kaempferol $>$ nicotine $>$ n-butylidenephthalide $>$ riluzole. Nicotine, kaempferol, and n-butylidenephthalide have to value almost near to each other.

In case of NMDA receptor antagonist activity, the phytochemicals does not have a good value even levodopa shown in Fig. 10. Resveratrol has the highest value, but it is only 0.232 which is not much more than levodopa (0.186). The compound which shows the NMDA receptor antagonist activity, their values lie almost in the same range or slightly differ from each other

Only two compounds resveratrol and l-theanine have more values than levodopa rest are having less than levodopa. Other compounds having NMDA receptor antagonist activity are as follow: Resveratrol $>$ l-theanine $>$ levodopa $>$ zingerone $>$ syringic acid $>$ baicalein $>$ kaempferol $>$ n-butylidenephthalide $>$ rosmarinic acid $>$ shogaol $>$ trehalose $>$ nicotine. 


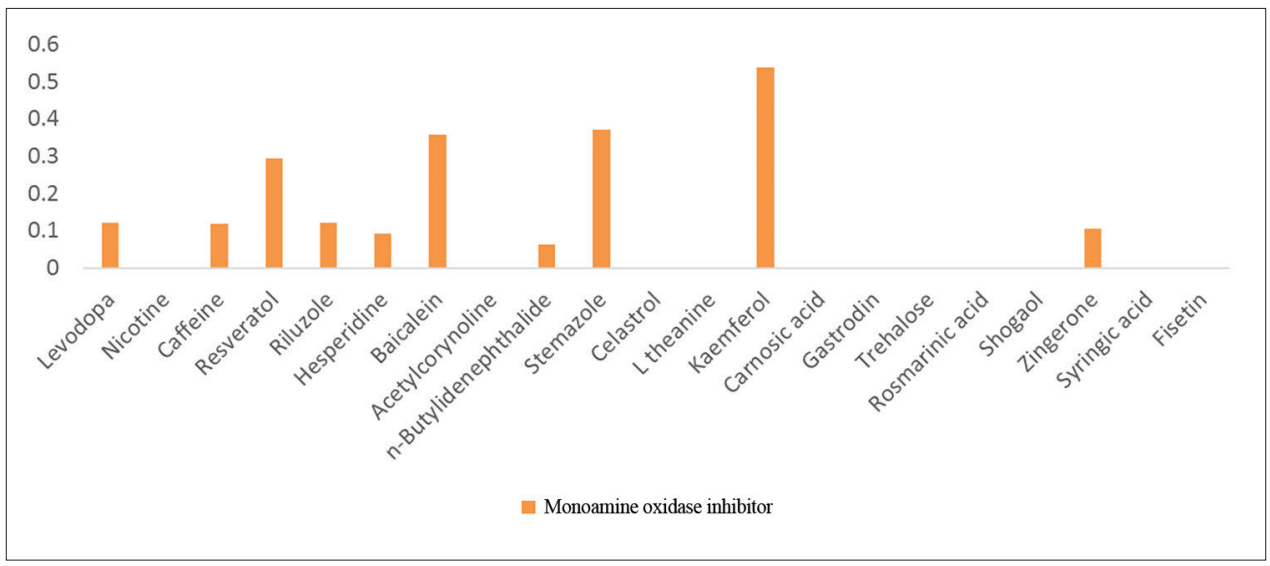

Fig. 8: Monoamine oxidase inhibiting activity of all compounds with respect to levodopa

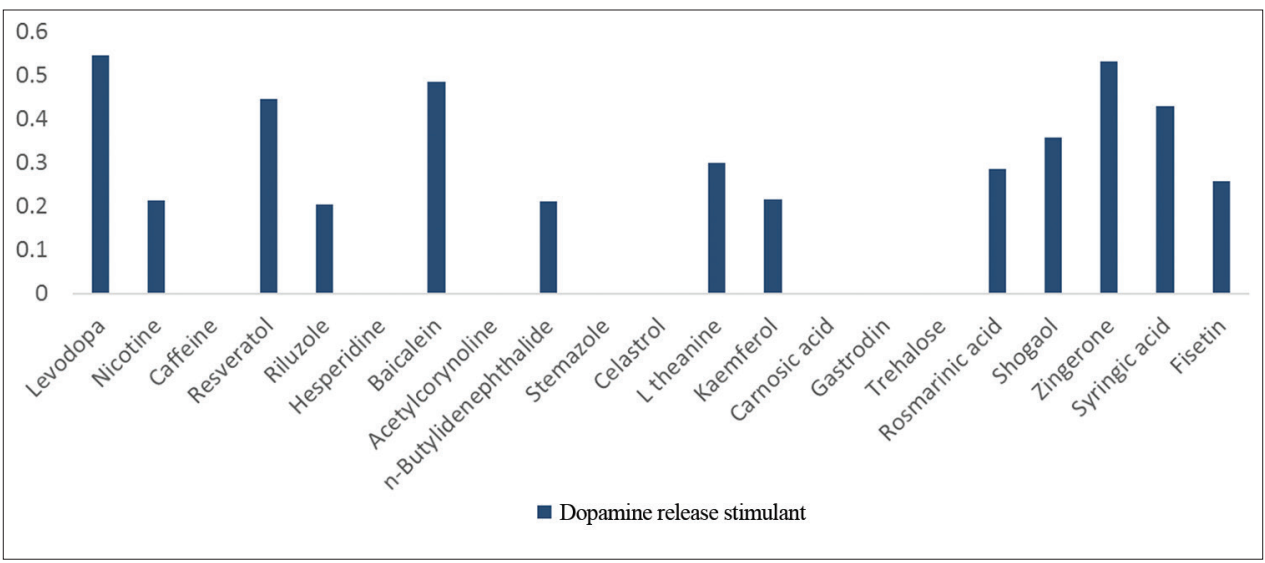

Fig. 9: Dopamine release stimulant activity of all compounds with respect to levodopa

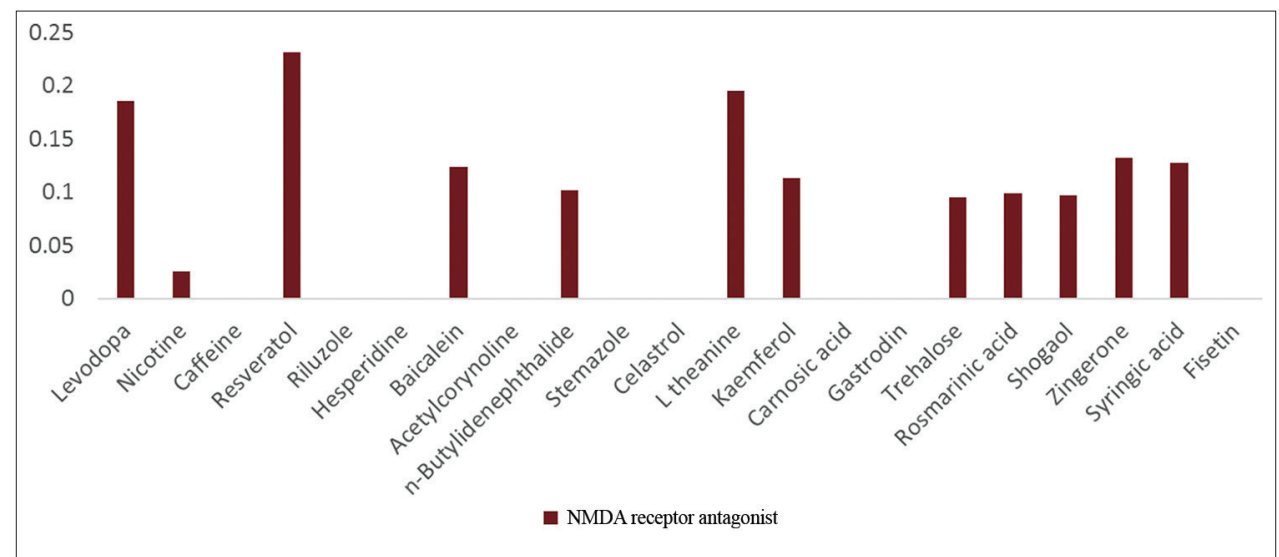

Fig. 10: N-methyl D-aspartate receptor antagonist activity of all the compounds with respect to levodopa

Being a standard drug therapy for PD, levodopa does not found to have a good antiparkinsonian activity, when compared to certain phytochemicals as shown in Fig. 11. Riluzole was found to have the highest antiparkinsonian activity among the phytochemicals and also more than levodopa. Carnosic acid, l-theanine, syringic acid, and n-butylidenephthalide have values near to each other, but syringic acid and n-butylidenephthalide have the same activity values.

Various phytochemicals are present in plants, but only few were explored for their pharmacological activities and rest are unexplored. Testing every compound by hit and trial method for pharmacological activity is not an easy task as it is tedious and costly. However, with the help of PASS, a pathway can be generated to evaluate the phytochemical for a particular pharmacological activity. PASS not only provides a supportive information for the pre-explored phytochemicals but also provides information regarding their hidden potential activities which previously not known.

\section{CONCLUSION}

From the above study, it can be concluded that PASS provides an informative data to support the reported activities of the phytochemicals. It can also help the researcher to decide and to prepare a protocol for 


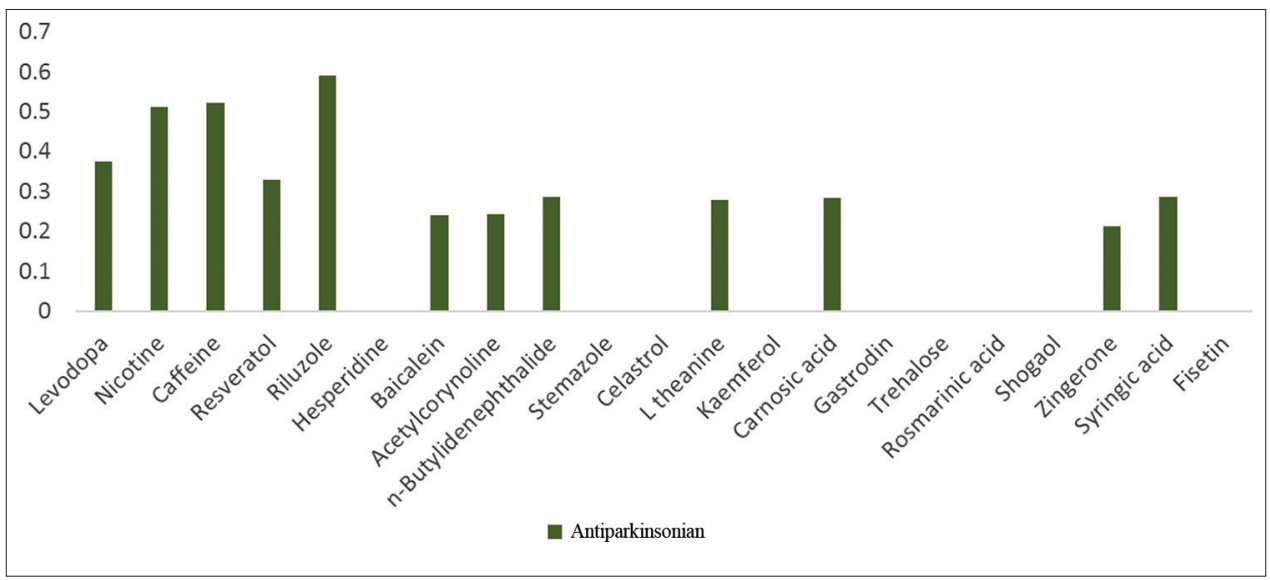

Fig. 11: Antiparkinsonian activity of all compounds with respect to the levodopa

testing a new phytochemical for a particular pharmacological action as well as to test a pre-reported phytochemical for a new activity.

\section{REFERENCES}

1. Shahpiri Z, Bahramsoltani R, Farzaei MH, Farzaei F, Rahimi R. Phytochemicals as future drugs for Parkinson's disease: A comprehensive review. Rev Neurosci 2016;27:651-68.

2. Gopalakrishna A, Alexander SA. Complex and multifaceted illness. J Neurosci Nurs 2015;47:320-6.

3. Bassani TB, Gradowski RW, Zaminelli T, Barbiero JK, Santiago RM, Boschen SL, et al. Neuroprotective and antidepressant-like effects of melatonin in a rotenone-induced Parkinson's disease model in rats. Brain Res 2014;1593:95-105.

4. Moon HE, Paek SH. Mitochondrial dysfunction in Parkinson's disease. Exp Neurobiol 2015;24:103.

5. Bais S, Gill NS, Kumar N. Neuroprotective effect of Juniperus communis on chlorpromazine induced Parkinson disease in animal model. Chin J Biol 2015;2015:3-9.

6. Sharifi H, Mohajjel Nayebi A, Farajnia S, Haddadi R. Effect of buspirone, fluoxetine and 8-OH-DPAT on striatal expression of bax, caspase-3 and bcl-2 proteins in 6-hydroxydopamine-induced hemiparkinsonian rats. Adv Pharm Bull 2015;5:491-5.

7. Jamkhande PG, Barde SR. Evaluation of anthelmintic activity and in silico PASS assisted prediction of Cordia dichotoma (Forst.) root extract. Anc Sci Life 2014;34:39-43.

8. Khurana N, Ishar MP, Gajbhiye A, Goel RK. PASS assisted prediction and pharmacological evaluation of novel nicotinic analogs for nootropic activity in mice. Eur J Pharmacol 2011;662:22-30.

9. Anand A, Sharma N, Khurana N. Prediction of activity spectra of substances assisted prediction of biological activity spectra of potential anti-Alzheimer's phytoconstituents. Asian J Pharm Clin Res 2017;10:13-21.

10. Habibyar AF, Sharma N, Khurana N. PASS assisted prediction and pharmacological evaluation of hesperidin against scopolamine induced amnesia in mice. Eur J Pharmacol 2016;789:385-94.

11. Katzenschlager R, Lees AJ. Treatment of Parkinson's disease: Levodopa as the first choice. J Neurol 2002;249 Suppl 2:II19-24.

12. Quik M, Parameswaran N, McCallum SE, Bordia T, Bao S, McCormack A, et al. Chronic oral nicotine treatment protects against striatal degeneration in MPTP-treated primates. J Neurochem 2006;98:1866-75.

13. Khadrawy YA, Salem AM, El-Shamy KA, Ahmed EK, Fadl NN, Hosny EN. Neuroprotective and therapeutic effect of caffeine on the rat model of Parkinson's disease induced by rotenone. J Diet Suppl 2017;14:553-72.

14. Wang Y, Xu H, Fu Q, Ma R, Xiang J. Protective effect of resveratrol derived from Polygonum cuspidatum and it's liposomal form on nigral cells in parkinsonian rats. J Neurol Sci 2011;304:29-34.

15. Araki T, Kumagai T, Matsubara M, Ido T, Imai Y, Itoyama $\mathrm{Y}$, et al. Protective effect of riluzole on MPTP-induced depletion of dopamine and its metabolite content in mice. Metab Brain Dis 2000;15:193-201.

16. Antunes MS, Goes AT, Boeira SP, Prigol M, Jesse CR. Protective effect of hesperidin in a model of Parkinson's disease induced by 6-hydroxydopamine in aged mice. Nutrition 2014;30:1415-22.
17. Mu X, He G, Cheng Y, Li X, Xu B, Du G, et al. Baicalein exerts neuroprotective effects in 6-hydroxydopamine-induced experimental Parkinsonism in vivo and in vitro. Pharmacol Biochem Behav 2009;92:642-8.

18. Fu RH, Wang YC, Chen CS, Tsai RT, Liu SP, Chang WL, et al. Acetylcorynoline attenuates dopaminergic neuron degeneration and $\alpha$-synuclein aggregation in animal models of Parkinson's disease. Neuropharmacology 2014;82:108-20.

19. Fu RH, Harn HJ, Liu SP, Chen CS, Chang WL, Chen YM, et al. $\mathrm{N}$-Butylidenephthalide protects against dopaminergic neuron degeneration and $\alpha$-synuclein accumulation in Caenorhabditis elegans models of Parkinson's disease. PLoS One 2014;9:e85305.

20. Guo Z, Xu S, Du N, Liu J, Huang Y, Han M, et al. Neuroprotective effects of stemazole in the MPTP-induced acute model of Parkinson's disease: Involvement of the dopamine system. Neurosci Lett 2016;616:152-9.

21. Cleren C, Calingasan NY, Chen J, Beal MF. Celastrol protects against MPTP- and 3-nitropropionic acid-induced neurotoxicity. J Neurochem 2005:94:995-1004.

22. Cho HS, Kim S, Lee SY, Park JA, Kim SJ, Chun HS. Protective effect of the green tea component, L-theanine on environment toxins-induced neuronal cell death. Neurotoxicology 2008;29:656-62.

23. Shen LI. Neuroprotective effect of kaempferol against a 1-Methyl4-phenyl-1, 2, 3, 6-tetrahydropyridine-induced mouse model of Parkinson's disease. Biol Pharm Bull 2011;34:1291-6.

24. Wu CR, Tsai CW, Chang SW, Lin CY, Huang LC, Tsai CW, et al. Carnosic acid protects against 6-hydroxydopamine-induced neurotoxicity in in vivo and in vitro model of Parkinson's disease: Involvement of antioxidative enzymes induction. Chem Biol Interact 2015;225:40-6.

25. Kumar H, Kim IS, More SV, Kim BW, Bahk YY, Choi DK. Gastrodin protects apoptotic dopaminergic neurons in a toxin-induced Parkinson's disease model, evidence-based complement. Altern Med 2013;2013:514095.

26. Sarkar S, Chigurupati S, Raymick J, Mann D, Bowyer JF, Schmitt T, et al. Neuroprotective effect of the chemical chaperone, trehalose in a chronic MPTP-induced Parkinson's disease mouse model. Neurotoxicology 2014;44:250-62.

27. Du T, Li L, Song N, Xie J, Jiang H. Rosmarinic acid antagonized 1-methyl-4-phenylpyridinium (MPP+)-induced neurotoxicity in MES23.5 dopaminergic cells. Int J Toxicol 2010;29:625-33.

28. Park G, Kim HG, Ju MS, Ha SK, Park Y, Kim SY, et al. 6-shogaol, an active compound of ginger, protects dopaminergic neurons in Parkinson's disease models via anti-neuroinflammation. Acta Pharmacol Sin 2013;34:1131-9.

29. Kabuto H, Nishizawa M, Tada M, Higashio C, Shishibori T, Kohno M, et al. Zingerone [4-(4-hydroxy-3-methoxyphenyl)-2-butanone] prevents 6-hydroxydopamine-induced dopamine depression in mouse striatum and increases superoxide scavenging activity in serum. Neurochem Res 2005;30:325-32.

30. Rekha KR, Selvakumar GP, Sivakamasundari RI. Effects of syringic acid on chronic MPTP/probenecid induced motor dysfunction, dopaminergic markers expression and neuroinflammation in C57BL/6 mice. Biomed Aging Pathol 2014;4:95-104.

31. Patel MY, Panchal HV, Ghribi O, Benzeroual KE. The neuroprotective effect of fisetin in the MPTP model of Parkinson's disease. J Park Dis 2012;2:287-302. 